\title{
Is God His Essence? The Logical Structure of Aquinas' Proofs for this Claim
}

\author{
Tomasz Kąkol
}

Received: 5 February 2013 / Revised: 5 April 2013 /Accepted: 14 April 2013 /

Published online: 17 August 2013

C The Author(s) 2013. This article is published with open access at Springerlink.com

\begin{abstract}
In this article I consider whether Aquinas' arguments for the claim that God is His essence are conclusive, and what was his purpose of upholding this thesis. I show his proofs from Summa Theologiae and Summa Contra Gentiles to be problematic and argue that the defense of Aquinas' views on that matter suggested by certain remarks of P. T. Geach is flawed.
\end{abstract}

Keywords Accident $\cdot$ Aquinas $\cdot$ Essence $\cdot$ God

\section{Introduction}

The traditional philosophy of God maintains that God is His essence. Among philosophers who defended this view Thomas Aquinas is a classical example. In this article I consider whether Aquinas' arguments are conclusive and what was his purpose of upholding the thesis about divine essence. I show his proofs to be problematic.

The essence of a particular thing is a factor responsible for what the very thing is (a horse, say). For the Aristotelian philosopher, a thing cannot lose its essence and keep on existing - if you make the horse into meat, this horse will lose its essence. A given thing, apart from being something (a horse, say) and existing (provided that it exists at all), is (usually, if not always) such and such - we could say that it has certain properties. These properties are either entailed by the essence of this thing (as being able to neigh) or not (as having its hair done), yet they are said to belong to it.

A very rough version of the article was presented during the international conference Analytical Approaches to Thomas Aquinas, 26-27th May 2012 in Krakow (Poland). I would like to thank the organizers for their hospitality and encouraging me to write its full version. I would dedicate it to Karol, my newborn son.

T. Kąkol ( $\square)$

Institute of Philosophy, Sociology and Journalism, University of Gdańsk, ul. Bażyńskiego 4, 80-952 Gdańsk, Poland

e-mail: null_set@poczta.onet.pl 
Aristotelian philosophers called these determinations accidents (proper ones as regards the former example, improper ones in the case of the latter). ${ }^{1}$ Although the essence of God as traditionally conceived is undoubtedly different from that of a horse, it seems that the thesis stating that divine essence is just identical with God Himself is not a trivial one and - from the point of view of common sense (that does not have the decisive voice in philosophy; it is a philosophical starting point, though) - is very suspicious. But that is why the arguments for this stance along with motivations of its defender seem to be more interesting.

We start from Summa Theologiae (ST) because arguments provided there are more concise, then we turn to Summa Contra Gentiles (SCG).

\section{Summa Theologiae}

* q. 3, a. 3 (Quod Deus est idem quod sua essentia ${ }^{2}$ - "That God is identical with His essence") - the argument is: cum Deus non sit compositus ex materia et forma ("for God is not composed of matter and form").

But on the contrary, compare De Ente et Essentia, c. 4: ...et quia in istis substantiis quidditas non est idem quod esse, ideo sunt ordinabiles in praedicamento, et propter hoc invenitur in eis genus et species et differentia, quamvis earum differentiae propriae nobis occultae sint (...). Accidentia autem propria substantiarum immaterialium nobis ignota sunt; unde differentiae earum nec per se nec per accidentales differentias a nobis significari possunt (".... and since in these substances [i. e. immaterial ones] their essence is not the same as their existence, we can place them in the order of categories, and in virtue of this we find in them kind, species and difference, though we do not know what their proper differences look like (...). We do not know proper accidents of immaterial substances; hence, their differences can be signified by us neither in themselves, nor through accidental differences").

The fact that their proper accidents are not known by us does not mean that they do not exist. Even if our interpretation of this part of De Ente... is wrong, or if Thomas

\footnotetext{
${ }^{1}$ I think we should use this informal characterization since I know of no precise formalization of Aquinas' notions of accident and essence. For example, let's look whether the definition of a proper accident, given in (Brown 2005, 51f - probably the closest to what Thomas says about accidents) could be satisfied by, e. g., omnipotence.

This definition is: " $x$ is a proper accident $=\mathrm{df}(1) x$ is an accident [that is, something, that has a quiddity to which it belongs to exist in another as in a subject - TK], (2) there is a species $F$ such that $x$ belongs to $F$, (3) if $y$ is the subject in which $x$ inheres, then (i) $y$ belongs to species $A$, and (ii) for any time $t$ at which $y$ exists, $x$ inheres in $y$, and (iii) for any $z$ such that $z$ belongs to $A$, an accident belonging to $F$ inheres in $z$ ". To answer the question one must establish first whether, i. a., omnipotence can exist in another (say, God) as in a subject (see clause (1) and the antecedent of (3)), but this is precisely what is at issue when we inquire whether God is deprived of accidents! Alternatively, check the simplified (and modified) version of this definition: $x$ is a proper accident of $y=\mathrm{df}$ (1) $x$ is not $y$ 's essence, (2) for any time $t$ at which $y$ exists, $x$ inheres in $y$, and (3) for all $z$, if $z$ is of the same species as $y$, then $x$ inheres in $z$ as well. From this Thomas would infer that green is God's accident (!), since all three clauses are satisfied in this case (it is not God's essence, the antecedent of (2) is false since God is extra-temporal being, and, finally, the antecedent of (3) is also false for God does not belong - according to Aquinas - to any species).

${ }^{2}$ Aquinas frequently writes in the texts under consideration 'essentia seu quidditas sive natura' ("essence, i.e. quiddity, i.e. nature") etc. All Aquinas' texts quoted in the article come from the monumental www.corpusthomisticum.org (access: 15.06.12). Translations are my own.
} 
has backed away from his early position, it is still not evident that having accidents entails being composed of matter and form.

* q. 3, a. 6 (Quod in Deo non potest esse accidens - "That there cannot be accidents in God").

Argument 1): ...subiectum comparatur ad accidens, sicut potentia ad actum, subiectum enim secundum accidens est aliquo modo in actu. Esse autem in potentia, omnino removetur a Deo, ut ex praedictis patet ("A subject is related to accident as potency to act, since a subject is in act in a certain respect in virtue of an accident. Yet from what we have said it is evident that we rejected that God is in any respect in potency").

Thomas means here his famous prima via ("the first way"), i. e. his proof ex motu ("from the movement") for the existence of God. But on the contrary: the problem is that prima via is unsound or at least contradicts what Aquinas believes of the free will. ${ }^{3}$ Why?

\section{Digression. What is Wrong with the Prima Via}

One of the relatively new formalizations of prima via is in (Nieznański 2006). Its logical base is first-order classical predicate calculus with identity.

Abbreviations:

' $\operatorname{MAD}(x, y, e)$ ' means ' $y$ causes $x$ to exist'

' $x \mathrm{PO} e$ ' means ' $x$ is in potency to esse ("existence")'

' $x \mathrm{AC} e$ ' means ' $x$ is in act to esse'

Definitions:

where $\mathrm{R}$ is a binary relation: $x \mathrm{R}^{*} y:=\exists \mathrm{n} x \mathrm{R}^{\mathrm{n}} y$. In turn, $\mathrm{R}^{\mathrm{n}}$ is defined recursively as $\mathrm{R}^{1}:=\mathrm{R} \wedge \forall \mathrm{k}\left(\mathrm{R}^{\mathrm{k}+1}:=\mathrm{R}^{\mathrm{k}} \mathrm{oR}\right)$, where RoR is superposition, i.e.: $x \mathrm{RoR} y:=\exists z$ $(x \mathrm{R} z \wedge z \mathrm{R} y)$

$\mathrm{v}(y):=\exists x \operatorname{MAD}(y, x, e)$

$y \mathrm{MO} x:=\operatorname{MAD}(y, x, e)$ (that shows that ternary relation is not necessary)

MO is unfounded : $=\forall x, y\left(y \mathrm{MO}^{*} x \wedge x \neq y \rightarrow \mathrm{v}(x)\right)$

$x$ is (one of?) the first unmoved mover(s?) ${ }^{4}:=\exists y\left(y \mathrm{MO}^{*} x \wedge x \neq y \wedge \neg \mathrm{v}(x)\right)$

According to Nieznański, Thomas assumes the following six axioms:

1. $\exists y \mathrm{v}(y)$

2. $\forall x, y(y \mathrm{MO} x \rightarrow y \mathrm{PO} e)$

3. $\forall x, y(y \mathrm{MO} \rightarrow x \mathrm{AC} e)$

4. $\neg \exists x(x \mathrm{PO} e \wedge x \mathrm{AC} e)$

5. $\forall x, y(y \mathrm{MO} \rightarrow(\mathrm{v}(x) \rightarrow(x \neq y \rightarrow \exists z(x \mathrm{MO} z \wedge x \neq z))))$

6. $\forall y\left(\mathrm{v}(y) \rightarrow \exists x\left(y \mathrm{MO}^{*} x \wedge x \neq y \wedge \neg \mathrm{v}(x)\right)\right)$

\footnotetext{
$\overline{3}$ Or at least I think that should believe - Dr. Petr Dvořák has shown me that Aquinas while trying to reconciliate omnipotence and omniscience of God with the human free will, in the end lapsed into an unexpected determinism (P. Dvořák, The Dilemma of Infallible Divine Causation and Human Freedom in Thomas Aquinas and Thomism: A Contemporary Analytic Approach, paper presented at the conference mentioned in footnote 1).

${ }^{4}$ This remark reminds us that we have not established yet the (possible) uniqueness of God.
} 
They imply that:

7. $\forall x, y(y \mathrm{MO} x \rightarrow y \mathrm{PO} e \wedge x \mathrm{ACe})($ from 2,3$)$

8. $\neg \exists x x \mathrm{MO} x$ (from 4,7 )

9. $\forall x, y(y \mathrm{MO} \rightarrow x \neq y)($ from 8$)$

10. $\exists x, y\left(y \mathrm{MO}^{*} x \wedge x \neq y \wedge \neg \mathrm{v}(x)\right)($ from 1,6$)$

11. $\exists x$ ( $x$ is (one of?) the first unmoved mover(s?)) (from 10 and definition)

It becomes apparent that four axioms are in fact superfluous: it suffices to assume 1 and 6 to prove the existence of (one of?) the first unmoved mover(s?). But then the proof seems trivial: from the very strong axiom 6 (that can be called after B. Bolzano "the principle of foundation") we almost immediately have the conclusion. Therefore, applying the principle of charity to Thomas' argument, I believe that in fact Nieznański did not reconstruct the prima via.

One could argue here: "never mind, we need the premise that there is no potency in God, and the argument shows that this is the case". But from 3 and 4 it follows that every cause of existence has no potency to esse and even if 3 may be true in the case of esse substantiale (substantial existence, or the existence of substance), it is not obvious in the case of esse accidentale (accidental existence, or the existence of accident): suppose that I freely decide to write this sentence. The esse of my decision has a (ultimate) cause (if we believe in free will) in me. But I was not in act to this esse, yet in potency. ${ }^{5}$ Therefore, even if Thomas had in mind here esse substantiale, the truth of 3 is compatible with being in potency to esse accidentale.

I take J. Bocheński's last formalization (Bocheński 2003, 49-57), as corrected by Nieznański due to several logical errors (see Nieznański 2006, 30f), as more adequate. The logical basis is the same.

Abbreviations:

' $\operatorname{MAD}(x, y, z)$ ' means ' $x$ is moved (in the Aristotelian sense of change) by $y$ to $z$ ' ' $x$ POy' means ' $x$ is in potency to $y$ '

' $x \mathrm{AC} y$ ' means ' $x$ is in act to $y$ '

\section{Definitions:}

where $\mathrm{R}$ is a binary relation (or a ternary one provided that its third argument is hidden because it is unessential): $x \mathrm{R}^{*} y:=\exists \mathrm{n} x \mathrm{R}^{\mathrm{n}} y$. In turn, $\mathrm{R}^{\mathrm{n}}$ is defined recursively as $\mathrm{R}^{1}:=\mathrm{R} \wedge \forall \mathrm{k}\left(\mathrm{R}^{\mathrm{k}+1}:=\mathrm{R}^{\mathrm{k}} \mathrm{oR}\right)$, where RoR is superposition, i. e. $x \operatorname{RoR} y:=\exists z(x \mathrm{R} z \wedge z \mathrm{R} y)$.

MAD is unfounded (in Aquinas' words: procedit in infinitum - "proceeds in infinity"): $=\forall x, y\left(y \mathrm{MAD}^{*} x \wedge x \neq y \rightarrow \mathrm{v}(x)\right)$

$\mathrm{v}(x):=\exists y, z \operatorname{MAD}(x, y, z)$

$\mathrm{M}(x):=x$ is (one of?) the first unmoved mover(s?)

According to Bocheński, Aquinas assumes seven axioms:

1. $\forall x, y(\operatorname{MAD}(x, y, z) \rightarrow x \mathrm{PO} z)$

2. $\forall x, y(\operatorname{MAD}(x, y, z) \rightarrow y \mathrm{AC} z)$

\footnotetext{
${ }^{5}$ Compare (Chisholm 1982). Interestingly, Nieznański objects that Bocheński's formalization (see below) has the similar inconvenience (Nieznański 2006, 32). Interpreted as referring to the esse accidentale, 3 will probably be false also in the deterministic world; I chose a free act as a more convincing example.
} 
3. $\neg \exists x, z(x \mathrm{PO} z \wedge x \mathrm{AC} z)$

4. $\exists x, y, z(\operatorname{MAD}(x, y, z) \wedge \mathrm{v}(y))$

5. $\forall x, y, z(\operatorname{MAD}(x, y, z) \wedge x \neq y \wedge \mathrm{v}(y) \rightarrow \exists t, u(\operatorname{MAD}(y, t, u) \wedge y \neq t))$

6. $\exists x, y, z(\operatorname{MAD}(x, y, z) \wedge x \neq y \wedge \mathrm{v}(y) \wedge \exists t, u(\operatorname{MAD}(y, t, u) \wedge y \neq t)) \rightarrow \neg \mathrm{MAD}$ is unfounded

7. $\neg \mathrm{MAD}$ is unfounded $\rightarrow \exists \mathrm{M}(x)$

From these we can infer what follows:

8. $\forall x, y, z(\operatorname{MAD}(x, y, z) \rightarrow x \neq y)$ (from $1,2,3)$

9. $\exists x, y, z(\operatorname{MAD}(x, y, z) \wedge x \neq y \wedge \mathrm{v}(y))$ (from 4, 8)

10. $\exists x, y, z(\operatorname{MAD}(x, y, z) \wedge x \neq y \wedge \mathrm{v}(\mathrm{y}) \wedge \exists t, u(\operatorname{MAD}(y, t, u) \wedge y \neq t))($ from 5, 9)

11. $\exists \mathrm{M}(x)$ (from $6,7,10$ )

Philosophers who criticize "the five ways" usually reject 6 but - being aware that 6 is not obvious from the point of view of pure logic - I personally do not find anything unreasonable in maintaining this version of the principle of foundation. ${ }^{6}$ Instead, I believe that Thomas should refute 2 (and - for the same "libertarian" reason -5 as well), because I need not be in act to what I intend to do. ${ }^{7}$ Similarly, to change the spatial location ( $z$ in 5) of the stick $(x)$ freely, I $(y)$ need not be moved by anything else $(t)$. That is why I find this way of proving that God is a pure act unconvincing.

After this digression let us return to the main thread, i. e. arguments from q. 3, a. 6. Argument 2): quia Deus est suum esse (q. 3, a. 4) ("for God is [identical with] His existence"). But on the contrary, Thomas at most proved that God's essence is His existence (another question is whether something, being its own existence, is deprived of accidents). It would indeed follow if, for example, God were His own essence, but this is equivalent to the thesis that is yet to be proved.

Thomas' advocate can suggest a more charitable interpretation. Namely, let us analyze q. 3, a. 4 (and later, if needed, the parallel text from SCG, i. e. c. 22). The first $\operatorname{argument}^{8}$ is invalid, since Thomas neglects the possibility that existence can be a part of essence. The second one is erroneous, since it invokes premises from the prima via, which we have just undermined. ${ }^{9}$ In the third one he claims: ...illud quod habet esse et non est esse, est ens per participationem. (...) Si igitur non sit suum esse, erit ens per participationem, et non per essentiam. Non ergo erit primum ens, quod absurdum est dicere ("something that has existence and is not identical with the

\footnotetext{
${ }^{6}$ The same goes for the Nieznański's proposal mentioned above. What I oppose is that his reconstruction fits Thomas' text.

${ }^{7}$ In the previous version of this passage I wrote that 8 should be rejected since I could change myself. An anonymous referee pointed out to me that "the proposition: $<<$ I can change myself $>>$ is not precise enough. It implies a composition of a human being from $\langle<\mathrm{I}\rangle>$ and $\langle<$ myself $>>$, what is unconvincing. It contradicts the principle of sufficient reason (...). Besides, we cannot act without eating, which supplies us with the energy. We are able only to direct this energy without creating, increasing or decreasing it". I would say that his second sentence is false, yet the third one could be true and that is why now I am not sure whether to deny 8 . I agree with the rest of the referee's comment, but I hold that this does not contradict the possibility of selfchangeability: it is me (again, if we believe in free will) who is to direct the energy coming from the outside! 8 ...quia quidquid est in aliquo quod est praeter essentiam eius, oportet esse causatum vel a principiis essentiae (...); vel ab aliquo exteriori ("for it is necessary that everything which is in something, and outside of the essence of that in which it is, is caused either by the principles of essence (...); or by something external to this thing").

${ }^{9}$ Cum igitur in Deo nihil sit potentiale ("for there is nothing potential in God").
} 
existence, is a being through participation. (...) So if God is not [identical with] His existence, He will be being through participation, not through His essence. Hence, He will not be the first being, and it is an absurd to say so"). 'Primum ens' denotes here the first cause (from "the second way") or the being necessary through itself (from "the third way"). Nevertheless, assuming that these "ways" are sound arguments, ${ }^{10}$ I can see no inference from "there is the first cause (or being necessary through itself)" to "this being is identical with its existence". 11

Argument 3): ...omne quod est per se, prius est eo quod est per accidens. Unde, cum Deus sit simpliciter primum ens, in eo non potest esse aliquid per accidens. Sed nec accidentia per se ${ }^{12}$ in eo esse possunt, sicut risibile est per se accidens hominis. Quia huiusmodi accidentia causantur ex principiis subiecti, in Deo autem nihil potest esse causatum, cum sit causa prima ("Everything, which is by itself, is prior to what is by accident. Hence, since God is by His own nature the prime being, nothing can be in Him by accident. Neither can any proper accidents be in Him, as, for example, being able to laugh is a man's proper accident; because accidents of that kind have their cause in the subject's principles. Yet nothing, which is in God, can have any cause, since God is the first cause").

This is a compact version of the first argument from q. 3, a. 4 - to see this, it suffices to modify this proof from q. 3, a. 4, so as it concerns accidents, instead of esse:

...quidquid est in aliquo quod est praeter essentiam eius, oportet esse causatum vel a principiis essentiae, sicut accidentia propria consequentia speciem, ut risibile consequitur hominem et causatur ex principiis essentialibus speciei; vel ab aliquo exteriori, sicut calor in aqua causatur ab igne. Si igitur aliquid (scilicet accidens) sit in Deo, necesse est quod vel sit causatum ab aliquo exteriori, vel a principiis essentialibus eiusdem rei. (...) Hoc autem non potest dici de Deo, quia Deum dicimus esse primam causam efficientem ("it is

\footnotetext{
${ }^{10}$ The Reader curious about what (if anything) is wrong with the four remaining "ways" can notice the following facts: 1 . As for "the second way". Replace Bocheński's axiom 3 with the one stating that the binary relation of being the efficient cause $(C)$ is irreflexive and take aside 1 and 2, then replace 'MAD' with ' $\mathrm{C}$ ' in the others and read ' $\mathrm{v}(x)$ ' as ' $x$ is caused' and ' $\mathrm{M}(x)$ ' as ' $x$ is (one of?) the first cause(s?)'. I am not sure whether 3 is true, but even if we reject 3 , we immediately observe that if we accept 4 we can reasonably grant that the antecedent of 6 is true, and if we accept 6 (as I said above, I do accept it, anyway), we have 11. 2. With respect to "the third way". "The third way" can be seen problematic since it assumes the so-called Negative Principle of Plenitude (often parodied as one of the notorious Murphy's Laws): quod possibile est non esse, quandoque non est ("for something that may not be/exist, there is time when it is not/it does not exist"). It is true that it seems to be false, yet elsewhere I have shown that a very similar, equally "strange" claim follows from two intuitively correct premises (see Kakol 2007, 97f, 103). The real problem with "the third way" is that it assumes that the Negative Principle of Plenitude entails that si igitur omnia sunt possibilia non esse, aliquando nihil fuit in rebus ("so if everything may not be/exist, there was time when nothing was/existed"). It is evident that it should go like "so if everything (taken together at the same time!) may not be/exist, there is time when nothing is/exists"- but why to accept the antecedent? Fortunately, the counterpart of "the third way" in SCG (more precisely, it is in the fourth argument of c. 15) is deprived of these failures. 3. With regard to "the fourth way", it is unsound since it assumes that for every quality P (in the broadest possible sense) there is something that for every object having $\mathrm{P}$ this thing is the unique cause of $\mathrm{P}$ in them. Finally, "the fifth way" needs some development in, say, A. Flew's (see Flew 2007) style.

${ }^{11}$ The parallel text from SCG (c. 22) is not helpful here either. There are six arguments there but the difficulty is that the first one assumes that God is His quiddity; the second one once again assumes unjustified premise quod est per se necesse-esse, est suum esse ("what is through itself the necessary existence, is its existence"); the third one is the counterpart of the first one from ST, and although Thomas does not neglect here that existence can be a part of essence, he rejects it by appealing to the divine simplicity (c. 18, we will comment on this chapter later on); the same appeal is in the fifth one; the fourth one invokes the alleged lack of potency in God; finally, the last one is analogous to the third one from ST. ${ }^{12}$ AKA 'accidentia propria' ("proper accidents"), 'accidentia necessaria' ("necessary accidents") or 'accidentia inseparabilia' ("inseparable accidents").
} 
necessary that everything which is in something, and outside of the essence of that in which it is, is caused either by the principles of essence, as proper accidents following from the species, as being able to laugh belongs to a man, and the essential principles of the species are its cause, or by something external to this thing, as, e.g. fire is the cause of heat in water. So if there is something (that is, an accident) in God, it will be necessary that it is caused either by something external to God, or by His essential principles. (...) But we cannot say it about God, since God is the first efficient cause").

But on the contrary, that God does not have a cause (assuming that the secunda via is sound), does not imply that God cannot be the cause of the proper accident. Moreover, it does not exclude the possibility of existing of two Gods, one of them being the cause of the (improper) accident in another. The reason is that Thomas proved neither that God is unique (the attempts to prove it are in q. 11, a. 3) nor that He is the cause of everything.

To sum up, arguments from ST are inconclusive.

\section{Summa Contra Gentiles}

* c. 21 (Quod Deus est sua essentia - "That God is His essence").

Argument 1): Ostensum est autem in Deo nullam esse compositionem (c. 18). Deus igitur est sua essentia ("It has been shown that there is no composition in God (in Chapter 18). Hence, God is [identical with] His essence"). Let us analyze then c. 18:

Argument 1): ....in omni composito oportet esse actum et potentiam. (...) Quae enim actu sunt, non uniuntur nisi quasi colligata vel congregata, quae non sunt unum simpliciter. In quibus etiam ipsae partes congregatae sunt sicut potentia respectu unionis: sunt enim unitae in actu postquam fuerint in potentia unibiles. In Deo autem nulla est potentia ("there must be an act and a potency in every composite. (...) For [these] things which are in act are not unified unless, so to say, bound or aggregated, as not being one in and of itself. And in these things, their aggregated parts are in potency to being unified: for they are actually unified, after having been potentially unified. Yet, there is no potency in God").

But on the contrary: it has not been established that there is no potency in God, and even if it has, partes congregatae refer obviously to common mereological wholes, such as heaps, not to accidents.

Argument 2): Omne compositum posterius est suis componentibus. Primum ergo ens, quod Deus est, ex nullis compositum est ("every composite is posterior to its components. So the first being, which is God, is not composed of anything").

Here we could simply repeat the last 'but on the contrary' from the part devoted to the respective argument from ST.

Argument 3): Omne compositum est potentia dissolubile (...). Quod autem est dissolubile, est in potentia ad non esse. Quod Deo non competit: cum sit per se necesse-esse ("Every composition is potentially decomposable (...). What is decomposable, is potentially non-existent, which does not belong to God, since He is by Himself a necessary being [or: it is necessary by itself that He exists]").

But on the contrary: it may not hold for the composite of essence and proper accident(s).

Argument 4): Si igitur compositus esset Deus, haberet componentem: non enim ipse seipsum componere posset, quia nihil est causa sui ipsius; esset enim prius seipso, quod 
est impossibile. Componens autem est causa efficiens compositi. Ergo Deus haberet causam efficientem... ("if God were composed, He would have something composing Him, for He could not compose Himself, as nothing is the cause of itself: otherwise He would exist before Himself, which is impossible. And a thing composing is the efficient cause of a thing composed. Hence, God would have an efficient cause").

But on the contrary: as above.

Argument 5): In quolibet genere tanto aliquid est nobilius quanto simplicius: sicut in genere calidi ignis, qui non habet aliquam frigidi permixtionem. Quod igitur est in fine nobilitatis omnium entium, oportet esse in fine simplicitatis. Hoc autem quod est in fine nobilitatis omnium entium, dicimus Deum, cum sit prima causa: causa enim est nobilior effectu. Nulla igitur compositio ei accidere potest ("in every kind, the simpler something is, the more noble it is: for example, among hot things fire is such, as it is not mixed with anything cold. Thus, something that is the most noble of all beings, is the simplest. Yet, by God we mean something that is the most noble of all beings, because He is the first cause: for a cause is more noble than an effect. Hence, no composition can take place in Him").

But on the contrary: the first sentence is not justified; the same goes for quod Deus est in fine nobilitatis omnium entium et quod causa est nobilior effectu. Even if they were warranted, they would be consistent with such object having accidents.

Argument 6): In omni composito bonum non est huius vel illius partis, sed totius: nam partes sunt imperfectae respectu totius (...). Si ergo Deus est compositus, perfectio et bonitas eius propria invenitur in toto, non autem in aliqua eius partium. Et sic non erit in eo pure illud bonum quod est proprium ei. Non est ergo ipse primum et summum bonum ("in every composite, the good does not belong to this or that part, but to the whole: since parts are imperfect as compared to the whole (...). So, if God is composite, His proper perfection and goodness is found in the whole, not in some of His parts. Thus, there will not be in Him purely this good, which is proper to Him. Therefore, He is not the first and the highest good").

But on the contrary: it is not justified quod ipse est primum et summum bonum, and even if it were, we would have once again non sequitur.

Argument 7): Ante omnem multitudinem oportet invenire unitatem. In omni autem composito est multitudo. Igitur oportet id quod est ante omnia, scilicet Deum, omni compositione carere ("before each multiplicity one should find unity. But in every composite is multiplicity. Hence, it is necessary that this, which is before everything, namely God, is free of every composite").

But on the contrary: it has not been proven quod Deus est ante omnia. And even if it has, we would have the same flaw as above.

Coming back to the arguments from c. 21:

Argument 2): In Deo autem non sunt aliqua accidentia, ut ostendetur (c. 23). Est igitur ipse sua essentia ("but there are no accidents in God, as it will be shown (in chapter 23). Therefore, He is [identical with] His essence").

Once again we have to refer to c. 23 :

Argument 1):=ST, q. 3, a. 6, argument 2) (see above).

Argument 2): Accidents can be either proper or improper ones. If proper, see ST, q. 3, a. 3 above. If improper, this accident is caused, but this fact implies that God changes, contrary to quod Deus est primus motor separatus, omnino immobilis (c. 13) ("that God is the first, separated mover, in no respect movable"). 
But on the contrary, c. 13 is the counterpart of the prima via, but the prima via does not establish that there is no change in God. ${ }^{13}$

Argument 3):=ST, q. 3, a. 6, argument 1) (see above)

Argument 4): Cuicumque inest aliquid accidentaliter, est aliquo modo secundum suam naturam mutabile: accidens enim de se natum est inesse et non inesse. Si igitur Deus habet aliquid accidentaliter sibi conveniens, sequetur quod ipse sit mutabilis. Cuius contrarium supra demonstratum est ("Everything in which there is something accidentally, is somehow by its nature changeable ${ }^{14}$; for [improper] accident is by its nature being in and not being in [i. e. by its nature it has potentiality for being in something, and also for not being in something]. Hence, if God has something accidentally, it follows that He is changeable; whose opposite has been demonstrated above").

But on the contrary, once again it is based upon the prima via.

Argument 5):=c. 18, argument 5) (see above)

Argument 6): cum Deus est simplicissimus ("that God is the simplest", c. 18), i. e.=c. 21, argument 1) (see above)

Coming back to the arguments from c. 21:

Argument 3):=ST, q. 3, a. 3 (see above)

Argument 4): Essentia rei vel est res ipsa vel se habet ad ipsam aliquo modo ut causa (...). Sed nullo modo potest esse aliquid causa Dei ("the essence of a thing is either [identical with] this thing or is related to this thing in some way as a cause (...). Yet in no way something can be the cause of God").

But on the contrary, both the secunda via and its counterpart from SCG talk about efficient causes, not about formal ones.

Argument 5): Quod non est sua essentia, se habet secundum aliquid sui ad ipsam ut potentia ad actum. (...) Sed in Deo nulla est potentialitas, ut supra ostensum est (c. 16) ("Something that is not [identical with] its essence, is related in some of its aspect to that essence as potency to act. (...) But there is no potency in God, as it has been shown above (in chapter 16)").

But on the contrary, the first proposition is not justified, and neither is the second one. $^{15}$

To sum up, arguments from SCG are also inconclusive.

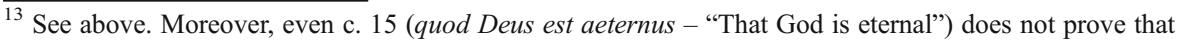
God is unchangeable: the first, the second and the fifth argument refer once again to the immutability of God allegedly proven in c. 13; the third and the fourth one indicate, respectively, quod Deus est prima causa et ens per se necessarium ("that God is the first cause and the being necessary through itself"), but this is irrelevant as to the question of change in God.

${ }^{14}$ More precisely, it holds for improper accidents only.

${ }^{15}$ Thomas' advocate will insist on checking chapter 16 . Here is the answer: the second, the fifth and the sixth argument refer to the immutability of God allegedly proven in c. 13; the first one assumes the Negative Principle of Plenitude, yet from this and from the eternity of God (c. 15) we can infer only that God is not possibile esse ("the possible existence", that means: the contingent being), yet it hardly excludes His purported (passive) potency (such an exclusion is assumed also in the third argument). Finally, the fourth one invokes once again participation, and as such it is unconvincing (compare with the third argument in ST, q. 3, a. 4 above): Unumquodque agit secundum quod est actu. Quod igitur non est totus actus, non toto se agit, sed aliquo sui. Quod autem non toto se agit, non est primum agens: agit enim alicuius participatione, non per essentiam suam ("everything acts in virtue of its being in act. Thus, something that is not the whole act, does not act with the whole of itself, but with its part. Now, something that does not act with the whole of itself, is not the first agent: since it acts participating in something, not through its own essence").
} 


\section{Why Did Thomas Assert that God is His Essence and Concluding Remarks}

The question expressed above can be answered in various ways. The most natural response would be that Thomas thought that his thesis about divine essence is entailed by premises accepted by him. But one can also propose two other, complementary answers: firstly, his position concerning God's essence is necessary for proving other important theorems of his metaphysics of God; secondly, Aquinas found that thesis in the works of his authorities (including the Scripture). As for the former, if arguments for the claim that God is His essence were sound, we would be able to prove the uniqueness of God, provided that divine essence is unique (according to the first proof for the uniqueness of God in ST [ST, q. 11, a. 3]). Unfortunately, Aquinas did not prove the unicity of divine essence, which is also a crucial premise in the other two arguments for the uniqueness of God (the third proof from Scriptum super Sententiis [SsS, dist. II, q. 1, a. 1, sed contra, 4] and the ninth proof from SCG [SCG, c. 42]). On the other hand, with the additional assumptions of the Anselmian proposal that God is constituted by all and only perfections, and the law of identity of indiscernibles, we straightforwardly get the requested conclusion (the second proof for the uniqueness of God in, respectively, SsS, SCG and ST). But if that is so, what is the reason for constructing other proofs? Next, as regards the influence of authorities, Thomas quotes the Gospel according to St John (ego sum (...) vita ["I am (...) life"] - 14, 6) [ST, q. 3, a. 3], Augustine (in Deo nullum est accidens ["there is no accident in God"]) [SCG, c. 23] and Boethius (forma simplex non potest esse subiectum ["the simple form cannot be the subject" - i.e., the subject of accidents] and licet id quod est, aliquid aliud possit habere adiunctum, tamen ipsum esse nihil aliud adiunctum habere potest ["although something that is, can have something else added, the sole existence cannot"]) [ST, q. 3, a. 6]). The first quote is especially significant, and can be supplied with the reference to the first epistle general of John. In this letter the famous phrase Deus caritas est ("God is love") is expressed several times. The advocate of the theory of "purely theological influence" could argue as follows: Aquinas interprets the Scriptures as a kind of "revealed metaphysics" (the common example is his invoking Exodus 3, 14 [ego sum qui sum - "I am who I am"] in support for his thesis about the identity of essence and existence in God). Hence, the quoted phrases from John, which I suppose should be taken to be metaphors (for their literal meaning produces categorial fallacy), are conceived by Thomas as Deus vita/caritas est, non autem habet vitam/caritatem - "God is life/love, He does not have life/love".

It seems, however, that such a theory is too one-sided. It is true that, to a certain degree, Aquinas perceives Aristotle and other philosophers through the Scriptures, and in many cases even vice versa, yet it does not exclude the fact that he was defending the thesis about the divine essence because of rational motivations, not faith (he thought that he found in the Scriptures yet another confirmation of the thesis in question).

Furthermore, one can argue in favor of the claim in question with an appeal to the clarifications and arguments presented by Geach (1969). Take into consideration any characteristic (in the broadest sense possible) of God, such as that God is wise, God is loving (=God loves [somebody]), God is existing (=God exists), etc. Thomas maintains that the cause of the fact that a given object is $\mathrm{F}$ is this object's F-ness (or F-itas): that, in virtue of which (a quo) Socrates is a human being, is his humanity; that, in virtue of which Socrates exists (est), is his existence (esse). When we now ask whether Socrates is the cause of the fact that he exists, the answer will be negative and the same goes for his 
humanity. But in the case of God the situation is different: God is the first efficient cause not only as far as things are concerned, but also regarding facts. It would be unintelligible to think that, for example, when we hold that God is wise, this very fact is caused either by something other that God Himself, or this fact is a "brute" fact. Therefore, for every characteristic F of God, God is the cause of the fact that He is F. And since we have already said that it is in virtue of $x$ 's F-ness that $x$ is F, it follows that God $=$ God's F-ness. ${ }^{16}$ In particular, God is His wisdom, life, existence, etc. Even assuming (per impossibile) that God has an accident A, we obtain that God is His A-ness, from which it follows that A is not an accident at all. Moreover, suppose that God is F and it is so in virtue of there being another God, God*. ${ }^{17}$ Since God is F in virtue of God's F-ness, it follows that God* = God's F-ness. But it is a nonsense unless God* = God.

A. Plantinga argued that the view that God is His essence is equal to implicit atheism: to declare that God as traditionally conceived (hence, as a person) is His essence, which in turn is an abstract entity, does not differ substantially from the denial of God. ${ }^{18}$ Nevertheless, it seems that his argument can be weakened. In many areas of philosophy we encounter various so-called identity theses, which are notoriously understood by many as eliminativist theses: the strong psychophysical identity thesis (philosophy of mind), the identity of the good with certain so-called natural properties (metaethical naturalism of some sort), Deus sive Natura (Spinoza), in God essence is the same as existence (Aquinas), equating objects enduring through time with processes (the stance known as perdurantism $^{19}$ ), and so on. However, there remain the following four difficulties:

1. The claim that only in some cases there is no categorial difference between objects enduring through time and processes (such a stance could be called 'local perdurantism') is not at first glance contradictory, yet is highly counterintuitive. The same is true of claiming that we must give up on the distinction between, say, substance and accident, but only in some specific cases. Of course, one can always say that the Thomistic view of divine essence (as well as existence etc.) only shows that "God transcends all the categories", but this is hardly satisfactory: the negative (or apophatic) theology, without a bit of the positive one, is just saying farewell to reason. ${ }^{20}$

2. There is no straightforward path from the secunda via to the thesis concerning divine essence we examine. We need an argument to show that 'there is a thing that does not have any efficient cause' implies 'if that thing is F, then this very thing is the cause of that fact'.

3. Worse, if we substitute 'existence' for $\mathrm{F}$ in the second sentence, then these two propositions are contradictory.

4. Finally, assume that Socrates freely decides that he will run. If Socrates' run is that in virtue of which Socrates runs, then it is also the case that Socrates runs in virtue of himself. From these we can draw an absurd conclusion that Socrates $=$ his

\footnotetext{
${ }^{16}$ Compare (Geach 1969, 40).

${ }^{17}$ Compare the last 'but on the contrary' in Section 2.

${ }^{18}$ Compare (Plantinga 1980, 47).

19 This interpretation of perdurantism is argued for in (Kąkol 2013).

${ }^{20}$ An anonymous referee suggested that it could be the case that Aquinas indeed shows here "the limit of reason". However, at this point of his theological narration this would mean to surrender too quickly: for we are still at the beginnings of Summarum!
} 
run, for Socrates, not being God, is not "free" from the distinction between substance and accident.

To conclude, then, I hold that argumentation motivated by Geach's analysis is inconclusive.

Open Access This article is distributed under the terms of the Creative Commons Attribution License which permits any use, distribution, and reproduction in any medium, provided the original author(s) and the source are credited.

\section{References}

Bocheński, J. M. (2003). Gottes Dasein und Wesen. Logische Studien zur Summa Theologiae I (pp. 2-11). Muenchen: Philosophia Verlag.

Brown, C. M. (2005). Aquinas and the Ship of Theseus: Solving Puzzles About Material Objects. London and New York: Continuum.

Chisholm, R. M. (1982). Human Freedom and the Self. In G. Watson (Ed.), Free Will (pp. 24-35). New York: OUP.

Flew, A. (2007). There is a God: How the World's Most Notorious Atheist Changed His Mind. HarperCollins.

Geach, P. T. (1969). Form and Existence. In A. Kenny (Ed.), Aquinas: A Collection of Critical Essays (pp. 29-53). London and Melbourne: Macmillan.

Kąkol, T. (2007). A Formal Analysis of Selected Proofs by Aquinas for the Uniqueness of God. In Ch. Kanzian, M. Legenhausen (Eds.), Substance and Attribute. Western and Islamic Traditions in Dialogue (pp. 79-105). Ontos Verlag.

Kąkol, T. (2013). Ingardenowska ontologia czasu i procesu a prezentyzm (Ingarden's ontology of time and process and presentism). To appear in Filozofia Nauki (Philosophy of Science).

Nieznański, E. (2006). Prima via św. Tomasza w formalizacji Ojca Bocheńskiego (Father Bocheński’s formalization of St Thomas' prima via). Studia Philosophiae Christianae, 42(1), 27-35.

Plantinga, A. (1980). (1980). Does God Have A Nature? Marquette: Marquette University Press. 